University of Wollongong

Research Online

Faculty of Engineering - Papers (Archive)

Faculty of Engineering and Information

Sciences

2011

\title{
A GBH/LiBH4 coordination system with favorable dehydrogenation
}

Yanhui Guo

yanhui@uow.edu.au

Qinfen $\mathrm{Gu}$

Australian Synchrotron Company Ltd

Zaiping Guo

University of Wollongong, zguo@uow.edu.au

Jianfeng Mao

jm975@uowmail.edu.au

Hua-Kun Liu

University of Wollongong, hua@uow.edu.au

See next page for additional authors

Follow this and additional works at: https://ro.uow.edu.au/engpapers

Part of the Engineering Commons

https://ro.uow.edu.au/engpapers/1362

\section{Recommended Citation}

Guo, Yanhui; Gu, Qinfen; Guo, Zaiping; Mao, Jianfeng; Liu, Hua-Kun; Dou, S. X.; and Yu, Xuebin: A GBH/ $\mathrm{LiBH} 4$ coordination system with favorable dehydrogenation 2011, 7138-7144.

https://ro.uow.edu.au/engpapers/1362

Research Online is the open access institutional repository for the University of Wollongong. For further information contact the UOW Library: research-pubs@uow.edu.au 


\section{Authors}

Yanhui Guo, Qinfen Gu, Zaiping Guo, Jianfeng Mao, Hua-Kun Liu, S. X. Dou, and Xuebin Yu 
Title Id : 191055

Title : Journal of Materials Chemistry

ISSN : 0959-9428

Serial Type : Journal

Format: Print

Status : Active

SubjectCodes : CHEMISTRY

Publisher: Royal Society of Chemistry

Country : United Kingdom

Start Year: 1991

Content Type: Academic / Scholarly

Editorial Description : Publishes work of international significance on all aspects of materials chemistry.

Website : http://pubs.rsc.org/en/journals/journalissues/jm

Refereed: Yes

Abstracted/Indexed : Yes

Language: Text in English

Frequency : 48 times a year

Copyright $\odot 2010$ ProQuest LLC. All rights reserved. Ulrich's ${ }^{\mathrm{TM}}$, Ulrich's International Periodicals Directory ${ }^{\mathrm{TM}}$, Ulrich's Periodicals Directory ${ }^{\mathrm{TM}}$, ulrichsweb.com ${ }^{\mathrm{TM}}$ and The Ulrich's logo are trademarks of ProQuest LLC. 


\title{
Journal of \\ Materials Chemistry

\section{A $\mathrm{GBH} / \mathrm{LiBH}_{4}$ coordination system with favorable dehydrogenation $\uparrow$}

\author{
Yanhui Guo, ${ }^{a}$ Qinfen Gu, ${ }^{b}$ Zaiping Guo, ${ }^{c}$ Jianfeng Mao, ${ }^{c}$ Huakun Liu, ${ }^{c}$ Shixue Dou ${ }^{c}$ and Xuebin Yu ${ }^{* a c}$ \\ Received 22nd December 2010, Accepted 28th February 2011 \\ DOI: 10.1039/c0jm04485g
}

\begin{abstract}
A novel combined hydrogen storage system $\mathrm{LiBH}_{4} /\left[\mathrm{C}\left(\mathrm{NH}_{2}\right)_{3}\right]^{+}\left[\mathrm{BH}_{4}\right]^{-}(\mathrm{GBH})$ complexes were reported. By a short time ball milling of $\mathrm{LiBH}_{4}$ and guanidinium chloride, a series of new $\mathrm{LiBH}_{4} / \mathrm{GBH}$ complexes were produced. It was found that the two potential hydrogen storage materials exhibited a mutual dehydrogenation improvement, releasing $>10.0 \mathrm{wt}$. $\%$ of fairly pure $\mathrm{H}_{2}$ from $\mathrm{LiBH}_{4} / \mathrm{GBH}$ below $250^{\circ} \mathrm{C}$. Further investigations revealed that balancing the protic and hydridic hydrogens, and the complexation between $\mathrm{LiBH}_{4}$ and $\mathrm{GBH}$, are two important roles in the improvement of the dehydrogenation of this system, which may serve as an alternative strategy for developing a new metal borohydride/B-N-H system with favourable dehydrogenation.
\end{abstract}

\section{Introduction}

Solid-state hydrogen storage systems hold great promise for onboard applications. Key criteria for a successful system are high storage capacity, suitable thermodynamics, and fast hydriding and dehydriding kinetics. Nowadays, several methods, including physical means, sorbents, metal hydrides, chemical hydrides and ammonia complexes, have been developed to achieve these criteria. ${ }^{1}$ Among these expanding candidates, hydrides based on lightweight elements are considered the most feasible solution for meeting established long-term goals with respect to gravimetric and volumetric hydrogen capacities. ${ }^{1,2}$ One of the typical systems studied consists of alkali and alkali-earth metal borohydrides, such as $\mathrm{LiBH}_{4}, \mathrm{Mg}\left(\mathrm{BH}_{4}\right)_{2}$, and $\mathrm{Ca}\left(\mathrm{BH}_{4}\right)_{2}{ }^{1,3}$ Among them, $\mathrm{LiBH}_{4}$ holds the maximum hydrogen capacity of $18.4 \mathrm{wt} . \%$. However, the poor thermodynamic and kinetic properties of this borohydride are insurmountable drawbacks to its practical application. ${ }^{3}$ Literature protocols showed that many additives including metals, ${ }^{4}$ hydrides, ${ }^{4-6}$ halides, ${ }^{6}$ oxides,${ }^{7}$ carbon ${ }^{8}$, or nano-confinement ${ }^{9}$ can improve the dehydrogenation and rehydrogenation properties of $\mathrm{LiBH}_{4}$. However, normally a large amount of additives or templates should be utilized, which will largely reduce the hydrogen capacity of $\mathrm{LiBH}_{4}$-based composites.

Comparatively, B-N-H composites, from another typical lightweight element system, have also been of general interest for

${ }^{a}$ Department of Materials Science, Fudan University, Shanghai, 200433, China.E-mail: yuxuebin@fudan.edu.cn

${ }^{b}$ Australian Synchrotron Company Ltd., Victoria, 3168, Australia

${ }^{\circ}$ Institute for Superconducting and Electronic Materials, University of Wollongong, NSW, 2522, Australia

$\uparrow$ Electronic supplementary information (ESI) available: Experimental, Figures S1 to S11 and Table S1, S2. CCDC reference number 803990. For ESI and crystallographic data in CIF or other electronic format see DOI: $10.1039 / \mathrm{c} 0 \mathrm{jm} 04485 \mathrm{~g}$ chemical hydrogen storage recently, providing high weightpercent hydrogen materials where the corresponding protic and hydridic character of the hydrogens on the nitrogen and boron, respectively, allow a facile $\mathrm{H}_{2}$ release pathway. ${ }^{1} \mathrm{Up}$ to now, a series of $\mathrm{B}-\mathrm{N}-\mathrm{H}$ materials, such as ammonia borane (AB), ${ }^{10}$ metal amidoboranes $(\mathrm{LiAB}, \mathrm{NaAB}),{ }^{11}$ guanidinium borohydride $(\mathrm{GBH}),{ }^{12}$ hydrazine borane (HB), ${ }^{13}$ ammonia borohydride complexes, ${ }^{14}$ etc. ${ }^{15}$ have been developed. All these candidates were low or moderate temperature hydrogen-supply sources with relatively large capacities. Among them, GBH with a theoretical $\mathrm{H}_{2}$ capacity of $13.5 \mathrm{wt} . \% \mathrm{H}_{2}$ was found to be a promising, lowcost, reliable, and safe high-density chemical hydrogen storage source for applications where fast hydrogen generation on demand is required. ${ }^{12}$ However, along with hydrogen evolution, a significant release of ammonia is also observed during heating, which is fatal for fuel cell operation. To overcome this drawback, common strategies for the $\mathrm{B}-\mathrm{N}-\mathrm{H}$ systems, i.e. additives and nano-confinement, may be used for the modification of $\mathrm{GBH}$, but the hydrogen capacity reduction is inevitable. Therefore, it is meaningful to develop a new strategy to improve the hydrogen storage properties of these promising candidates, without reducing their hydrogen capacities. In this paper, we report a novel combined system of $\mathrm{LiBH}_{4} / \mathrm{GBH}$ complexes. Interestingly, our results showed that the two potential hydrogen storage materials exhibited a significant mutual dehydrogenation improvement. The binary system shows improved dehydrogenation compared with $\mathrm{LiBH}_{4}$ and GBH alone, releasing $>10.0$ wt. $\%$ of fairly pure $\mathrm{H}_{2}$ from $\mathrm{LiBH}_{4} / \mathrm{GBH}$ below $250{ }^{\circ} \mathrm{C}$. It revealed that balancing the protic and hydridic hydrogens, and the complexation between $\mathrm{LiBH}_{4}$ and GBH are two important factors that account for this improvement. Further studies suggested that this method could serve as a general strategy for the modification of metal borohydride and $\mathrm{B}-\mathrm{N}-\mathrm{H}$ systems, as well as developing new lightweight element systems with favourable dehydrogenation. 


\section{Experimental}

\section{Reagents and synthesis}

The raw materials were obtained commercially, namely, $\mathrm{LiBH}_{4}$ (95\%), $\mathrm{NaBH}_{4}(95 \%), \mathrm{Ca}\left(\mathrm{BH}_{4}\right)_{2}(95 \%)$ (Alfa Aesar, USA) and guanidinium chloride (98\%) $\left(\mathrm{CH}_{5} \mathrm{~N}_{3} \cdot \mathrm{HCl}\right.$, Alfa Aesar, USA) were used without further purification, with all handling procedures conducted under an argon atmosphere. Approximately $0.5 \mathrm{~g}$ mixtures of $\mathrm{LiBH}_{4}-\mathrm{CH}_{5} \mathrm{~N}_{3} \cdot \mathrm{HCl}$ with various mole ratios of $1: 1,2: 1,3: 1$ and $4: 1$ were mechanically milled for $60 \mathrm{~min}$ (planetary QM-1SP2) under argon using stainless steel spheres with a ball-to-power ratio of $30: 1$ to produce $\mathrm{GBH}$, and $\mathrm{GBH} /$ $\mathrm{LiBH}_{4}$ mixtures with mole ratios of $1: 1,1: 2,1: 3$ and $1: 4$. The milling process was carried out alternating between 6 min of milling and 6 min of not milling, in order to avoid an increase in temperature of the powders in the vial. $\mathrm{NaBH}_{4}-\mathrm{CH}_{5} \mathrm{~N}_{3} \cdot \mathrm{HCl}$ and $\mathrm{Ca}\left(\mathrm{BH}_{4}\right)_{2}-\mathrm{CH}_{5} \mathrm{~N}_{3} \cdot \mathrm{HCl}$ mixtures were prepared using the same procedure. All the procedures of the powder handling both before and after milling were carried out in a glove box under an argon atmosphere.

\section{Instrumentation and analyses}

Hydrogen release property measurements were performed by thermogravimetry/differential thermal analysis (TG/DSC, STA 449 C) connected to a mass spectrometer (MS, QMS 403) using a heating rate of $10{ }^{\circ} \mathrm{C} \mathrm{min}-1$ under a 1 atm argon atmosphere. Typical sample quantities were $5-10 \mathrm{mg}$, which is sufficient for getting accurate results due to the high sensitivity of the employed equipment. Temperature-programmed desorption (TPD) was also performed to determine the decomposition behavior of the sample on a semi-automatic Sievert's apparatus, connected with a reactor filled with sample $(\sim 0.1 \mathrm{~g})$ under an argon atmosphere ( 1 bar) at a heating rate of $5{ }^{\circ} \mathrm{C} \mathrm{min}^{-1}$. For all calculations of hydrogen capacity, the content of $\mathrm{LiCl}$ was not considered.

The $\mathrm{H}_{2}$ and $\mathrm{NH}_{3}$ contents within the emission gas were determined using gravimetric and volumetric results. Firstly, the mass percent $\left(W_{\mathrm{p}}\right)$ and mole per gram $\left(M_{\mathrm{p}}\right)$ of gas released from the sample were calculated from the weights of the samples and volumetric results, then the mole proportion of $\mathrm{H}_{2}\left(C_{\mathrm{H}_{2}}\right)$ and $\mathrm{NH}_{3}\left(C_{\mathrm{NH}_{3}}\right)$ can be calculated from the follow two equations,

$$
\begin{gathered}
C_{\mathrm{H}_{2}}+C_{\mathrm{NH}_{3}}=1 \\
\left(\left(C_{\mathrm{H}_{2}} \times 2.02\right)+\left(C_{\mathrm{NH}_{3}} \times 17.03\right)\right) \times M_{\mathrm{p}}=W_{\mathrm{p}}
\end{gathered}
$$

High-resolution X-ray powder diffraction (XRD) data were collected on the Powder Diffraction Beamline, Australian Synchrotron by using a Mythen detector. For phase identification and structure determination, samples were loaded into predried $0.7 \mathrm{~mm}$ glass capillary tubes inside the argon atmosphere glove box, and sealed with vacuum grease for X-ray diffraction measurements. The decomposition behaviour of the sample was also studied by in situ XRD, by heating the sample with a Cybostar hot gas blower. For in situ high temperature measurements, the sample was kept under an argon atmosphere. The sample was then heated from $30{ }^{\circ} \mathrm{C}$ to $200^{\circ} \mathrm{C}$ at temperature intervals of $10{ }^{\circ} \mathrm{C}$, at a heating rate of $6^{\circ} \mathrm{C} \mathrm{min}-1$, and the data collected for $8 \mathrm{~min}$ at each point. The wavelength for all these measurements was $1.30419 \AA$ A.

The powder X-ray diffraction (XRD, Rigaku D/max 2400) measurements were also conducted to confirm the phase structure. Powders were spread and measured on a Si single crystal. Amorphous polymer tape was used to cover the surface of the powder to avoid oxidation during the XRD measurement.

FT-IR (Magna-IR 550 II, Nicolet) analyses were conducted to confirm the chemical bonds in the sample. Products were pressed with $\mathrm{KBr}$ and then loaded in a sealed chamber for the measurement.

Solid-state MAS NMR spectra were measured using a Bruker Avance $300 \mathrm{MHz}$ spectrometer, using a Doty CP-MAS probe with no probe background. The powder samples collected after the decomposition reaction was spun at $5 \mathrm{kHz}$ using $4 \mathrm{~mm} \mathrm{ZrO}_{2}$ rotors filled up in purified argon atmosphere glove boxes. A $0.55 \mu$ s single-pulse excitation was employed, with repetition times of $1.5 \mathrm{~s}$.

\section{Results and discussion}

\section{Hydrogen desorption properties}

Mass spectrometry (MS) and thermogravimetric (TG) analysis results for $\mathrm{GBH}$ and the $\mathrm{GBH} / \mathrm{LiBH}_{4}$ composites are shown in Fig. 1. For the GBH sample, a two-step decomposition was observed, with a total weight loss of $26.7 \mathrm{wt} . \%$ by $400{ }^{\circ} \mathrm{C}$. The first step is a mixed evolution of $\mathrm{H}_{2}$ and $\mathrm{NH}_{3}$, occurring between 90 to $150{ }^{\circ} \mathrm{C}$, while the second step from 150 to $400{ }^{\circ} \mathrm{C}$ is dominated by $\mathrm{NH}_{3}$ release. As no borane evolution was observed over the studied temperature range the weight loss may be ascribed to the release of $\mathrm{H}_{2}$ and $\mathrm{NH}_{3}$ (Fig. S1 $\dagger$ ). This decomposition performance is similar to that in a previous report. ${ }^{12}$ The fact that ammonia evolution without hydrogen occurs above $200{ }^{\circ} \mathrm{C}$ indicates only partial consumption of $\mathrm{NH}$ in the $\mathrm{GBH}$, which may result from insufficient $\mathrm{BH}$ in the initial system. In contrast, the MS results for the $\mathrm{GBH} / \mathrm{LiBH}_{4}$ (mole ratio of $1: 1$, named $\mathrm{S} 1$ ) and $\mathrm{GBH} / \mathrm{LiBH}_{4}$ (mole ratio of $1: 2$, named $\mathrm{S} 2$ ) show that the evolution of $\mathrm{NH}_{3}$ was suppressed and the release of $\mathrm{H}_{2}$ was significantly improved. Meanwhile, it shows that following

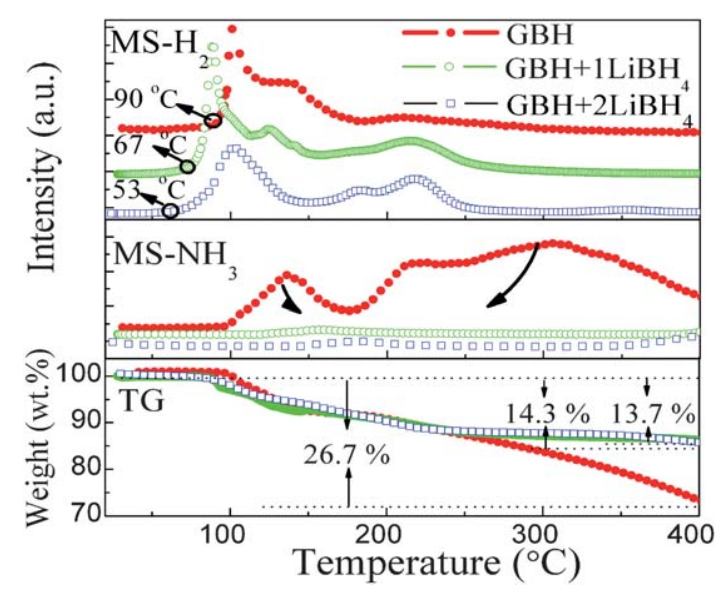

Fig. 1 MS of $m / e=2\left(\mathrm{H}_{2}\right)$ and $m / e=16\left(\mathrm{NH}_{3}\right)$, and TG profiles for $\mathrm{GBH} / \mathrm{LiBH}_{4}$ composites of various mole ratios. The heating rate is $10{ }^{\circ} \mathrm{C} \mathrm{min}^{-1}$. 
the first peak of hydrogen release at around $100{ }^{\circ} \mathrm{C}$, there is another major release peak centered at $220^{\circ} \mathrm{C}$; these events do not coincide with ammonia evolution as in GBH. Meanwhile, the onset temperature of the first dehydrogenation step was reduced from $90^{\circ} \mathrm{C}$ for $\mathrm{GBH}$ to $67^{\circ} \mathrm{C}$ and $53^{\circ} \mathrm{C}$ for samples $\mathrm{S} 1$ and $\mathrm{S} 2$, respectively. Hence, it is supposed that supplementation of more B-H may be an effective route to consume the excess $\mathrm{N}-\mathrm{H}$ bonds in $\mathrm{GBH}$, leading to continuing hydrogen release and reduction in the evolution of ammonia.

A summary of the gravimetric and volumetric measurement results, from the decomposition of $\mathrm{GBH}$ and $\mathrm{GBH} / n \mathrm{LiBH}_{4}$ composites (where $n=1,2,3$ ) are listed in Table 1. It can be seen that the ammonia concentration was reduced from $12.0 \%$ for GBH to $0.9 \%$ and $0.5 \%$ for S1 and S2, respectively. The isothermal dehydrogenation results from sample $\mathrm{S} 2$ (Fig. 2) show that favorable dehydrogenation kinetics can be obtained at temperatures above $100{ }^{\circ} \mathrm{C}$, from which hydrogen capacities of $4.3 \mathrm{wt} . \%, 5.4 \mathrm{wt} . \%$, and $7.7 \mathrm{wt} . \%$ were released within $30 \mathrm{~min}$ at 100,120 , and $150^{\circ} \mathrm{C}$, respectively. The fact that the hydrogen capacity is temperature dependent could be ascribed to its stepwise decomposition, as shown in Fig. 3, in which 3.1, 1.0, and 1.7 equiv. of $\mathrm{H}_{2}$ were released from the three stages. On further increasing the $\mathrm{LiBH}_{4}$ content in the mixture $\left(\mathrm{GBH}: \mathrm{LiBH}_{4}, 1: 3\right.$, named S3), the concentration of ammonia released was reduced to $<0.1 \%$, suggesting that the increased $\mathrm{LiBH}_{4}$ may further contribute to the ammonia suppression. In addition, an extra hydrogen desorption peak centered at $360^{\circ} \mathrm{C}$ appeared for the $\mathrm{S} 3$ sample (Fig. 4), which may be due to the decomposition of excess $\mathrm{BH}$ groups. However, this temperature is still $100^{\circ} \mathrm{C}$ lower than that of the pure $\mathrm{LiBH}_{4}$. The results above clearly indicate that a mutual dehydrogenation improvement between $\mathrm{LiBH}_{4}$ and GBH was achieved. However, attempts to recharge the decomposition products of $\mathrm{S} 2$ at $280{ }^{\circ} \mathrm{C}$ and $6.5 \mathrm{MPa}$ of $\mathrm{H}_{2}$ for up to $10 \mathrm{~h}$ were unsuccessful. This may be ascribed to its exothermic reaction (Fig. S2), which indicates that indirect chemical routes will have to be adopted to regenerate the composite from its decomposed products, as in the case of other boron-nitrogen systems. ${ }^{16}$

\section{Structure analyses}

The XRD results of $\mathrm{GBH} / \mathrm{LiBH}_{4}$ composites with various mole ratios revealed that the phase related to $\mathrm{LiBH}_{4}$ disappeared in the samples with mole ratios of $1: 1$ (S1) and $1: 2$ (S2), while

Table 1 Summary of $\mathrm{H}_{2}$ evolution from the $\mathrm{GBH} / \mathrm{Li}(\mathrm{Na}) \mathrm{BH}_{4}$ mixtures

\begin{tabular}{lllll}
\hline & & & & \multicolumn{2}{c}{ Mole } \\
Samples $^{a}$ & $\begin{array}{l}\text { wt.\% } \\
\text { Li(Na)BH }\end{array}$ & $\begin{array}{l}\text { wt.\% } \\
\mathrm{H}_{2} \text { capacity }\end{array}$ & $\begin{array}{l}\mathrm{mol}^{\circ} \% \\
\mathrm{H}^{b}\end{array}$ & $\begin{array}{l}\mathrm{H}_{2} \\
\text { Mole GBH }\end{array}$ \\
\hline GBH, this study & 0 & 7.4 & 88.0 & 2.8 \\
GBH + 1 $\mathrm{LiBH}_{4}$ & 22.5 & 12.1 & 99.1 & 5.9 \\
GBH + 2LiBH & 36.8 & 11.1 & 99.5 & 5.8 \\
GBH + 3LiBH & 53.4 & 10.2 & 99.9 & 7.1 \\
GBH + 2NaBH & 50.2 & - & 95.6 & 3.6 \\
GBH, ref. 12 & 0 & 10.6 & 95.9 & 3.9
\end{tabular}

${ }^{a}$ The $\mathrm{GBH} / \mathrm{Li}(\mathrm{Na}) \mathrm{BH}_{4}$ mixtures were heated in 1 bar argon from 30 to $300{ }^{\circ} \mathrm{C}$ with a heating rate of $5{ }^{\circ} \mathrm{C} \mathrm{min}{ }^{-1}$ for calculations of $\mathrm{H}_{2}$ evolution. ${ }^{b} \mathrm{H}_{2}$ content in the released gas.

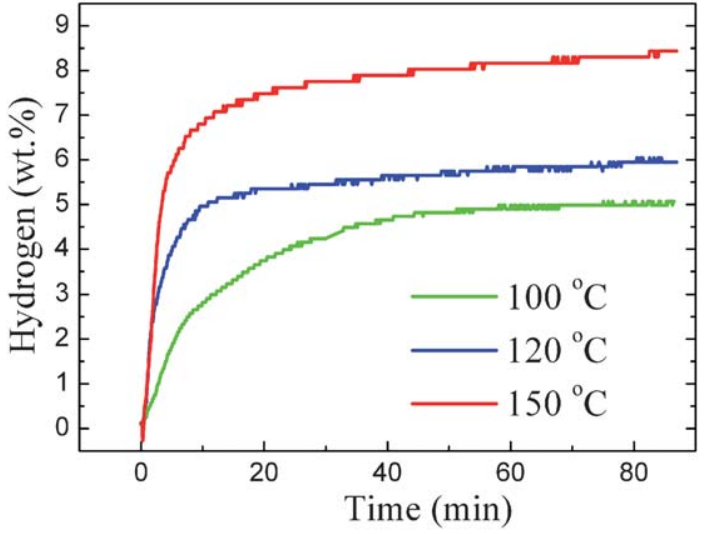

Fig. 2 Isothermal TPD results for $\mathrm{GBH} / 2 \mathrm{LiBH}_{4}$.

reappeared in the samples with mole ratios of $1: 3$ and $1: 4$ (Fig. S3 $\uparrow$ ), suggesting the reaction of GBH with $\mathrm{LiBH}_{4}$ to form new compounds with mole ratios below $1: 2$. It was supposed that the new compounds were complexes of $\mathrm{GBH}$ and $\mathrm{LiBH}_{4}$ based on the $\mathrm{N}: \rightarrow \mathrm{Li}^{+}$coordination bond. Furthermore, highresolution synchrotron X-ray diffraction results also revealed that diffraction patterns of S1 and S2 reaction products are different to those of the starting materials, and to each other; thereby further confirmed the reaction of GBH with $\mathrm{LiBH}_{4}$ to form new compounds (Fig. 5, S4 $\dagger$ ). The diffraction pattern of S1 was indexed to a monoclinic unit cell using program DICVOL06. ${ }^{17}$ The space group $P 1 a 1$ and $P 12 / a 1$ can be assigned based on systematic absences. As in $\mathrm{GBH}$, the $\mathrm{C}-\mathrm{N}$ skeletal structure of the cations remains mostly intact during the hydrogen release reaction, the starting model of the $\left[\mathrm{C}\left(\mathrm{NH}_{2}\right)_{3}\right]^{+}$ group taken from ${ }^{12}$ is treated as a rigid body with flexible torsion between $\mathrm{C}-\mathrm{N}$ atoms, and the $\left[\mathrm{BH}_{4}\right]^{-}$group as a tetrahedral rigid body with a fixed $\mathrm{B}-\mathrm{H}$ distance. The structure was solved as the space group $P 1 a 1$ (No. 7) by global optimization in direct space using the program FOX. ${ }^{18}$ Rietveld refinement was performed using Topas $\mathrm{v} 4.2,{ }^{19}$ and the refined lattice parameters are $a=17.2111(2) \AA, b=6.7501(1) \AA, c=13.2366(1) \AA$, and $\beta=108.5185(6)^{\circ}$. The result of Rietveld refinement is shown in Fig $\mathrm{S} 5, \dagger$ and the $\mathrm{LiC}\left(\mathrm{NH}_{2}\right)_{3}\left(\mathrm{BH}_{4}\right)_{2}$ crystal structure is shown in Fig. 6; the experiment, refinement results and atomic coordinates

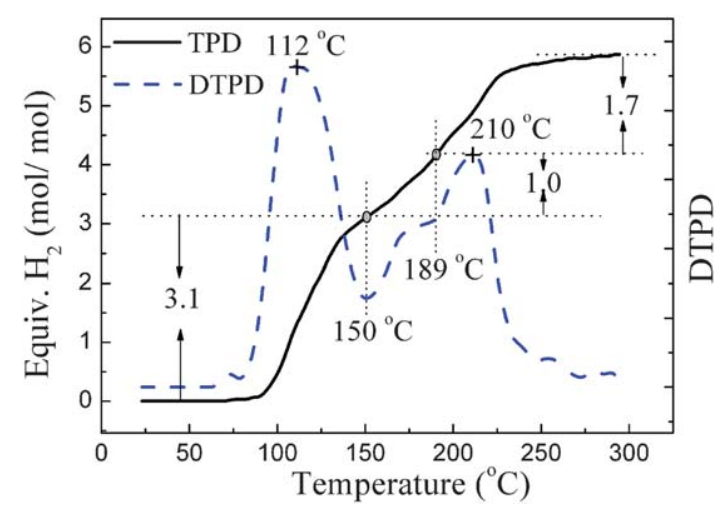

Fig. 3 TPD result and its differential curve (DTPD) for $\mathrm{GBH} / 2 \mathrm{LiBH}_{4}$. The heating rate is $5{ }^{\circ} \mathrm{C} \mathrm{min}$. 


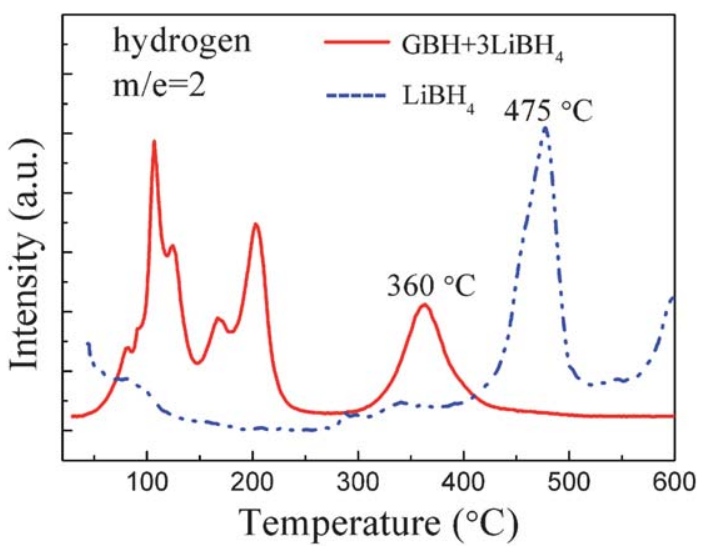

Fig. 4 MS profiles of $m / e=2\left(\mathrm{H}_{2}\right)$ for $\mathrm{LiBH}_{4}$ and $\mathrm{GBH} / 3 \mathrm{LiBH}_{4}$. The heating rate is $10{ }^{\circ} \mathrm{C} \mathrm{min}^{-1}$.

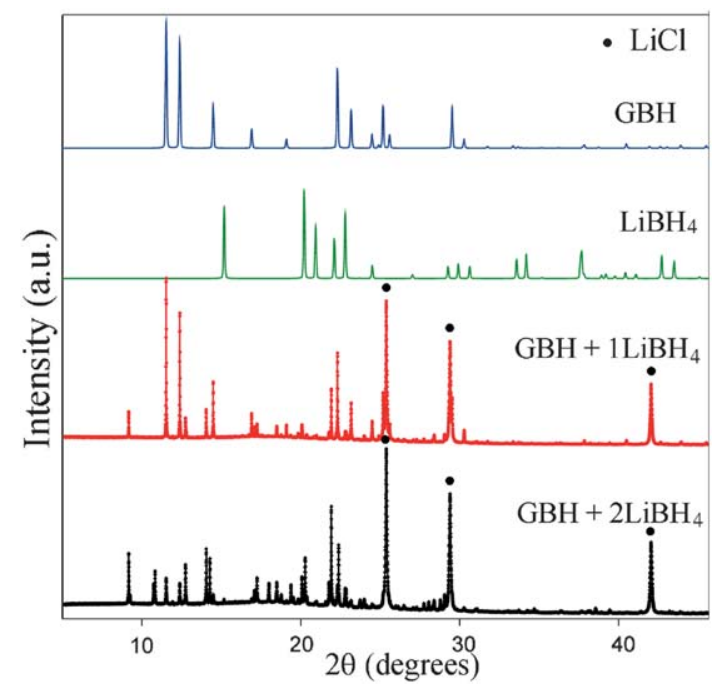

Fig. 5 Comparison of calculated XRD patterns of $\mathrm{GBH}, \mathrm{LiBH}_{4}$ with high-resolution XRD patterns of $\mathrm{GBH} / \mathrm{LiBH}_{4}$ and $\mathrm{GBH} / 2 \mathrm{LiBH}_{4}$.

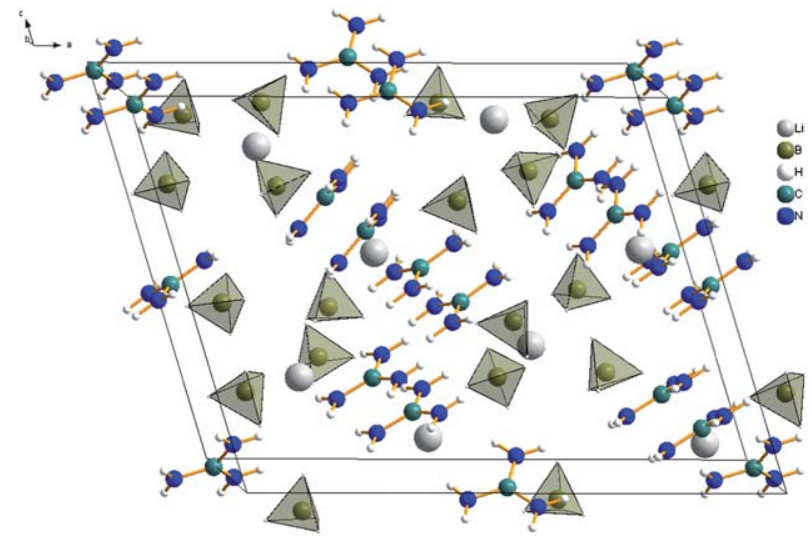

Fig. 6 3-dimensional crystal structure of $\mathrm{GBH}-\mathrm{LiBH}_{4}$. The light blue tetrahedral building blocks are $\mathrm{BH}_{4}{ }^{-}$.

are summarized in Table 2 and Table $\mathrm{S} 1 . \dagger$ The structure can be described as shifted stacked layers of $\mathrm{C}\left(\mathrm{NH}_{2}\right)_{3}$ molecules similar to the GBH structure, but with the Li atoms positioned in the voids between the layers. The $\mathrm{Li}$ atoms have two different types of coordination environments, Li1, $\mathrm{Li} 2$ are surrounded by $\mathrm{BH}_{4}$ and $\mathrm{NH}_{2}$ groups with an Li-B distance of approximately $2.652 \AA$ and $\mathrm{Li}-\mathrm{N}$ distances of 2.154 to $2.874 \AA$. Li3, Li4 are surrounded by $\mathrm{BH}_{4}$ groups with $\mathrm{Li}-\mathrm{B}$ distance 2.075 to $2.795 \AA$ A. A close contact distance between $\mathrm{Li}^{+}$and $\mathrm{N}$ of length $2.154 \AA$ and $2.214 \AA$ can be found, confirming the existence of the $\mathrm{N}: \rightarrow \mathrm{Li}^{+}$ coordinate bond.

To further understand the decomposition process for the $\mathrm{GBH} / \mathrm{LiBH}_{4}$ mixtures, high-resolution in situ XRD and ex-situ $\mathrm{XRD},{ }^{11} \mathrm{~B}$ solid state nuclear magnetic resonance $\left({ }^{11} \mathrm{~B} \mathrm{NMR}\right)$ and Fourier transform infrared (FTIR) measurements were conducted for S2 and GBH samples. Fig. 7 and Fig. S6† shows the high-resolution in situ XRD results of S2 ranging from 40$200{ }^{\circ} \mathrm{C}$. At $40{ }^{\circ} \mathrm{C}$, two main phases of $\mathrm{GBH} / \mathrm{LiBH}_{4}$ and $\mathrm{LiCl}$ were observed. Upon heating the sample in an argon atmosphere, no apparent change was observed until $90^{\circ} \mathrm{C}$ at which point all the peaks assigned to $\mathrm{GBH} / \mathrm{LiBH}_{4}$ disappeared, suggesting the decomposition of this composite, consistent with the thermal decomposition analysis. Meanwhile, no appearance of $\mathrm{LiBH}_{4}$ or other unknown phases were observed, indicating the involvement of $\mathrm{LiBH}_{4}$ in the dehydrogenation reaction and the amorphous structure of the decomposition products. Further heating leads to no apparent variation and finally yields products of only crystalline $\mathrm{LiCl}$ at $200{ }^{\circ} \mathrm{C}$. A similar trend was observed for $\mathrm{GBH}$ (Fig. 8) using ex-situ XRD analysis. The ${ }^{11} \mathrm{~B}$ NMR results for GBH showed a single boron species resonating at $-38.5 \mathrm{ppm}$ (Fig. 9), in agreement with previous reports. ${ }^{20}$ In the case of S2, an asymmetric B nucleus peak at $-40.5 \mathrm{ppm}$, between that of GBH and $\mathrm{LiBH}_{4}$, was observed, which may be assigned to $\mathrm{BH}_{4}{ }^{-}$, induced by $\mathrm{GBH}$ and $\mathrm{LiBH}_{4}$. Upon heating $\mathrm{S} 2$ to $150{ }^{\circ} \mathrm{C}$, a principal signal at around $-40.4 \mathrm{ppm}$ can be observed, corresponding to residual $\mathrm{BH}_{4}{ }^{-}$, and another three signals at $-4.6 \mathrm{ppm},-12 \mathrm{ppm}$, and $15.4 \mathrm{ppm}$ appear, which may be due to the combination of its $\mathrm{B}-\mathrm{H}$ and $\mathrm{N}-\mathrm{H}$, resulting in tetravalent borane nitrogen substances for four and two bound guanidinium units and minor tricoordinated $\mathrm{B}$ atoms, respectively. ${ }^{21}$ On heating S2 further to $300{ }^{\circ} \mathrm{C}$, two kinds of tridentate B nucleus peaks at 17.0 and $-2.0 \mathrm{ppm}$, corresponding to the formation of $\mathrm{BN}_{3}$ and/or $\mathrm{BN}_{2} \mathrm{H},{ }^{20}$ together with a signal at $-40.7 \mathrm{ppm}$ for the residue $\mathrm{BH}_{4}^{-}$, were observed. The above results indicate that the dehydrogenation mechanism in S2 may be similar to that of other $\mathrm{B}-\mathrm{N}-\mathrm{H}$ systems, ${ }^{11-15,20}$ i.e. hydrogen release occurs through the combination of $\mathrm{BH}$ and $\mathrm{NH}$, resulting in the formation of amorphous $\mathrm{BN}$-heterocycles.

FTIR results (Fig. 10) revealed that similar frequencies to those assigned to $\mathrm{B}-\mathrm{H}$ and $\left[\mathrm{C}\left(\mathrm{NH}_{2}\right)_{3}\right]^{+}$were present in $\mathrm{GBH}$ and $\mathrm{S} 2,{ }^{22}$ i.e., the $\mathrm{B}-\mathrm{H}$ stretching band in the region between $2400 \mathrm{~cm}^{-1}$ and $2200 \mathrm{~cm}^{-1}$, the $\mathrm{BH}_{2}$ deformation at $1123 \mathrm{~cm}^{-1}$, and the "scissor" motions of the $\mathrm{C}, \mathrm{N}$, and $\mathrm{H}$ atoms at $\sim 1600 \mathrm{~cm}^{-1}$. It is worth noting that the intensity of the $\mathrm{NH}_{2}$ scissors was distinctly reduced as the content of $\mathrm{LiBH}_{4}$ increased, which may result from the contribution of excess $\mathrm{B}-\mathrm{H}$ from $\mathrm{LiBH}_{4}$ forming novel $\mathrm{GBH} / \mathrm{LiBH}_{4}$ complexes with the $\mathrm{N}-\mathrm{H}$ bonds. Upon heating, vibrations assigned to $\mathrm{NH}$ groups still remained in $\mathrm{GBH}$, even after heating to $300{ }^{\circ} \mathrm{C}$, but the intensity of the $\mathrm{BH}$ groups was reduced gradually and almost disappeared during heat treatment to $300^{\circ} \mathrm{C}$, suggesting insufficient $\mathrm{B}-\mathrm{H}$ supplement to consume the $\mathrm{N}-\mathrm{H}$ in $\mathrm{GBH}$. Conversely, in the case of $\mathrm{S} 2$, vibrations assigned to $\mathrm{BH}$ groups remained during heat 
Table 2 Summary of experiment and crystallographic details for the GBH/LiBH 4 (S1) complex

Formula sum

Formula weight

Crystal system

Space-group

Cell parameters

Cell volume

$Z$

Calc. density

Pearson code

Wyckoff sequence

2theta, deg

Detector

Wavelength

$R_{\mathrm{B}}$

$R_{\mathrm{wp}}$

Gof

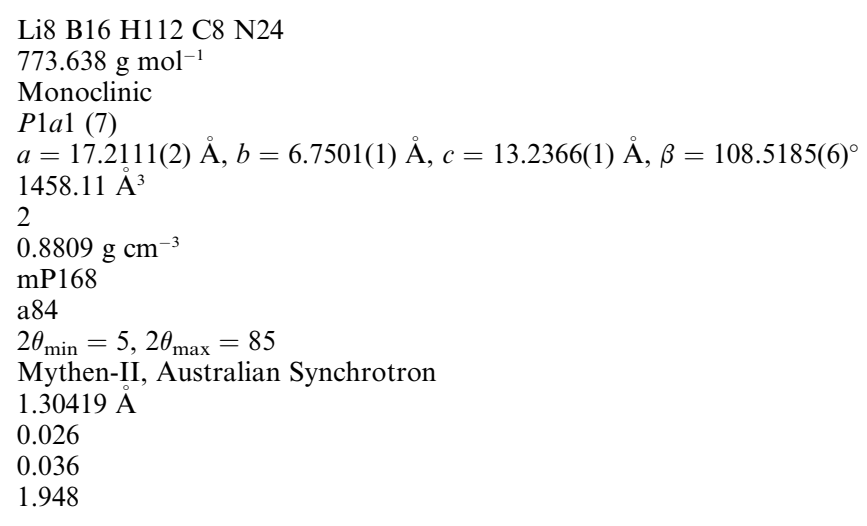

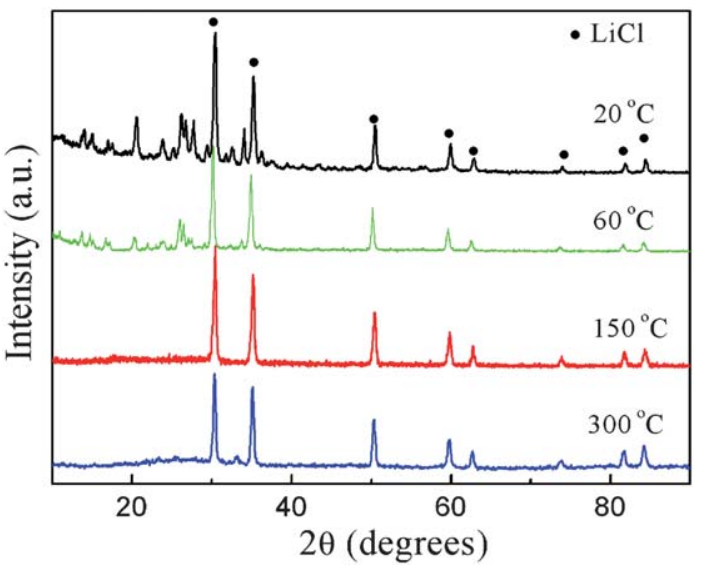

Fig. 8 Ex-situ XRD patterns for the GBH heating in argon.

treatment to $300{ }^{\circ} \mathrm{C}$, suggesting excessive supplement of $\mathrm{B}-\mathrm{H}$ bonds, but vibrations assigned to $\mathrm{NH}$ groups were reduced gradually and finally disappeared at $300{ }^{\circ} \mathrm{C}$, consistent with the step-wise dehydrogenation indicated by the temperature

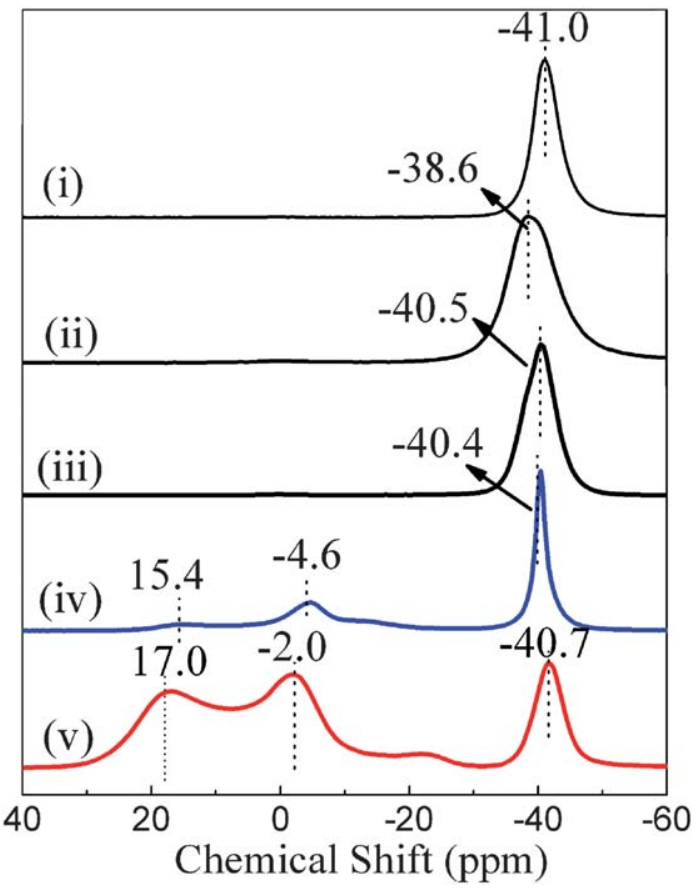

Fig. $9{ }^{11} \mathrm{~B}$ NMR data for $\mathrm{LiBH}_{4}$ (i), GBH (ii), and the GBH/2LiBH composite (iii); the latter has also been heated to $150{ }^{\circ} \mathrm{C}$ (iv) and $300{ }^{\circ} \mathrm{C}(\mathrm{v})$.

programmed desorption (TPD) result (Fig. 3), suggesting different or varied reactivity of the protonic $\mathrm{H}$ of $\mathrm{NH}_{2}$ in combination with $\mathrm{B}-\mathrm{H}$ groups during the decomposition. Meanwhile, a distinct intensity reduction for the $\mathrm{CN}_{3}$ vibrations was observed for both $\mathrm{GBH}$ and $\mathrm{S} 2$ upon heating, indicating variation of the $\mathrm{C}-\mathrm{N}$ skeletal structure.

According to the above analysis, although the intermediate phase is not very clear currently, it is concluded that the dehydrogenation of $\mathrm{GBH} / \mathrm{LiBH}_{4}$ composites is also based on the combination mechanism of $\mathrm{H}^{\delta+}$ and $\mathrm{H}^{\delta-},{ }^{11-15,20,23}$ and that $\mathrm{LiBH}_{4}$ is able to introduce an effective $\mathrm{H}^{\delta-}$ source through the coordination between $\mathrm{GBH}$ and $\mathrm{LiBH}_{4}$, forming new complexes, enabling the acheivement of the balance of $\mathrm{B}-\mathrm{H}$ and $\mathrm{N}-\mathrm{H}$ for the combination. $^{24}$ 


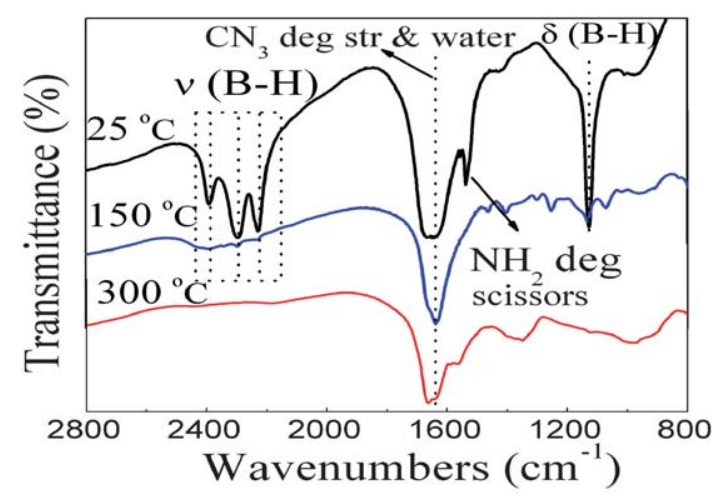

(a)

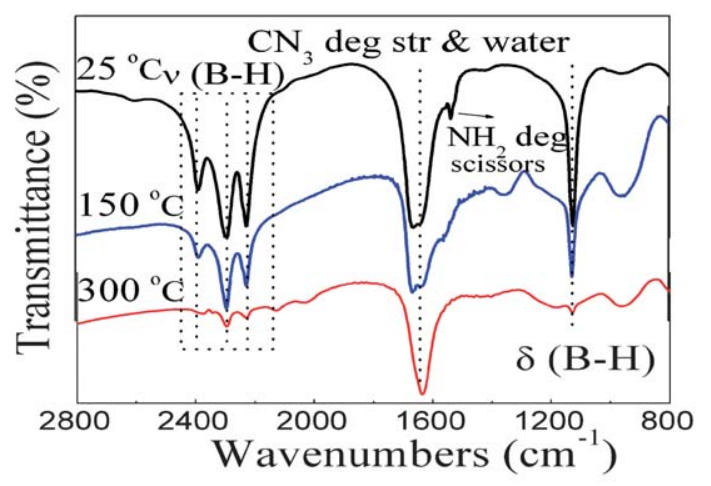

(b)

Fig. 10 FTIR spectra acquired at $25^{\circ} \mathrm{C}, 150{ }^{\circ} \mathrm{C}$ and $300^{\circ} \mathrm{C}$ from $\mathrm{GBH}$ (a) and $\mathrm{GBH} / 2 \mathrm{LiBH}_{4}$ (b).

\section{Proposed reaction pathway}

Based on the above results, the proposed reaction pathway for $\mathrm{GBH} / \mathrm{LiBH}_{4}$ is illustrated in Fig. 11 , where $\mathrm{M}^{n+}$ is $\mathrm{Li}^{+}$in this study. On mixing $\mathrm{GBH}$ with $\mathrm{LiBH}_{4}$, complexation between them occurs, resulting in $\mathrm{B}-\mathrm{H}$ and $\mathrm{N}-\mathrm{H}$ bonds that are in contact on a molecular scale, allowing close $\mathrm{H} \cdots \mathrm{H}$ contact (shorter than 2.4 $\AA$ ) in the $\mathrm{LiC}\left(\mathrm{NH}_{2}\right)_{3}\left(\mathrm{BH}_{4}\right)_{2}$ structure, which tends to promote hydrogen release in this system. During the dehydrogenation, the combination of $\mathrm{B}-\mathrm{H}$ and $\mathrm{N}-\mathrm{H}$ proceeds more easily. The adding of $\mathrm{LiBH}_{4}$ to $\mathrm{GBH}$ also contributes to the stability of the $\mathrm{NH}_{2}$ groups, thus reducing the ammonolysis of $\mathrm{GBH}$ to release ammonia. In order to verify this belief, other borohydrides, $\mathrm{NaBH}_{4}$ and $\mathrm{Ca}\left(\mathrm{BH}_{4}\right)_{2}$ were studied. In the case of $\mathrm{NaBH}_{4}$, no complexation occurred between $\mathrm{NaBH}_{4}$ and $\mathrm{GBH}$, resulting in independent decomposition of $\mathrm{GBH}$ and excess $\mathrm{NaBH}_{4}$, while clear complexation between $\mathrm{Ca}\left(\mathrm{BH}_{4}\right)_{2}$ and $\mathrm{GBH}$ were found, leading to a similar dehydrogenation to that of the $\mathrm{LiBH}_{4} / \mathrm{GBH}$

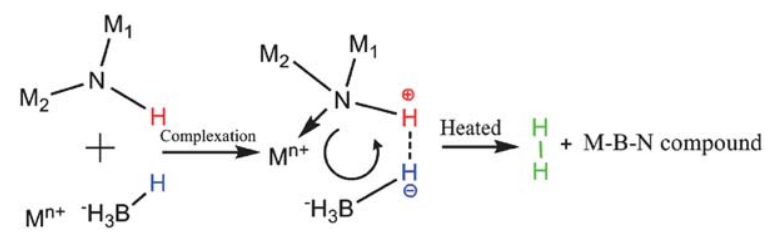

Fig. 11 A potential dehydrogenation pathway for the B-N-H system. systems, suggesting the rationality of the proposed pathway. The detailed results will be published elsewhere.

\section{Conclusions}

In summary, we have demonstrated that $\mathrm{GBH}$ is able to combine with $\mathrm{LiBH}_{4}$ to form $\mathrm{GBH} / n\left(\mathrm{LiBH}_{4}\right)$ complexes. These novel complexes exhibit exciting dehydrogenation properties, which not only significantly suppress the emission of ammonia from GBH, but also lead to lower dehydrogenation temperatures; thereby enabling a fairly pure stream of hydrogen, starting at around $60{ }^{\circ} \mathrm{C}$, during the thermal decomposition reaction, with a hydrogen capacity of $>10 \mathrm{wt} . \%$ for pure $\mathrm{LiBH}_{4} / \mathrm{GBH}$ below $250{ }^{\circ} \mathrm{C}$. Further investigation has revealed that balancing the contributing hydrogen sources, represented by the $\mathrm{N}-\mathrm{H}$ in $\mathrm{GBH}$ and by $\mathrm{B}-\mathrm{H}$ in $\mathrm{LiBH}_{4}$, together with the complexation of the two hydrides, are the two key factors for improving the dehydrogenation in this system. Such revelations are expected to lead to new strategies for designing future boron-nitrogen-hydrogen systems with favourable dehydrogenation processes.

\section{Acknowledgements}

This work was partially supported by the National Natural Science Foundation of China (Grant No. 51071047), the PhD Programs Foundation of Ministry of Education of China (20090071110053), the Program for New Century Excellent Talents in Universities (NCET-08-0135), an Australian Research Council (ARC) Discovery project (DP0878661). This research was undertaken on the Powder Diffraction beamline at the Australian Synchrotron, Victoria, Australia. We thank Dr Tania Silver for her reading of this paper and Dr Kia Wallwork for fruitful discussion.

\section{Notes and references}

1 W. Osborn, T. Markmaitree, L. L. Shaw, R. Ren, J. Hu, J. H. Kwak and Z. Yang, JOM, 2009, 61, 45-51; C. W. Hamilton, R. T. Baker, A. Staubitz and I. Manners, Chem. Soc. Rev., 2009, 38, 279-293; C. H. Christensen, R. Z. Sørensen, T. Johannessen, U. J. Quaade, K. Honkala, T. D. Elmøe, R. Køhler and J. K. Nørskov, J. Mater. Chem., 2005, 15, 4106-4108; R. Z. Sørensen, J. S. Hummelshøj, A. Klerke, J. B. Reves, T. Vegge, J. K. Nørskov and C. H. Christensen, J. Am. Chem. Soc., 2008, 130, 8660-8668; A. Klerke, C. H. Christensen, J. K. Nørskov and T. Vegge, J. Mater. Chem., 2008, 18, 2304-2310.

2 Y. E. Filinchuk, K. Yvon, G. P. Meisner, F. E. Pinkerton and M. P. Balogh, Inorg. Chem., 2006, 45, 1433-1435; Z. T. Xiong, G. T. Wu, J. J. Hu, Y. F. Liu, P. Chen and W. F. Luo, Adv. Funct. Mater., 2007, 17, 1137-1142; F. E. Pinkerton, M. S. Meyer, G. P. Meisner, M. P. Balogh and J. J. Vajo, J. Phys. Chem. C, 2007, 111, 12881-12885.

3 A. Züttel, P. Wenger, S. Rentsch, P. Sudan, Ph. Mauron and Ch. Emmenegger, J. Power Sources, 2003, 118, 1-7; M. F. Ingleson, J. P. Barrio, J. Bacsa, A. Steiner, G. R. Darling, J. T. A. Jones, Y. Z. Khimyak and M. J. Rosseinsky, Angew. Chem., Int. Ed., 2009, 48, 2012-2016; R. J. Newhouse, V. Stavila, S. J. Hwang, L. E. Klebanoff and J. Z. Zhang, J. Phys. Chem. C, 2010, 114, 5224-5232; L. L. Wang, D. D. Graham, I. M. Robertson and D. D. Johnson, J. Phys. Chem. C, 2009, 113, 20088-20096.

4 J. Yang, A. Sudik and C. Wolverton, J. Phys. Chem. C, 2007, 111, 19134-19140.

5 X. B. Yu, D. M. Granta and G. S. Walker, Chem. Commun., 2006, 3906-3908.

$6 \mathrm{M}$. Au, A. R. Jurgensen, W. A. Spencer, D. L. Anton, F. E. Pinkerton, S. Hwang, C. Kim and R. C. Bowman, J. Phys. 
Chem. C, 2008, 112, 18661-18671; Y. H. Guo, X. B. Yu, L. Gao, G. L. Xia, Z. P. Guo and H. K. Liu, Energy Environ. Sci., 2010, 3, 465-470.

7 X. B. Yu, D. M. Grant and G. S. Walker, J. Phys. Chem. C, 2008, 112, 11059-11062.

8 X. B. Yu, Z. Wu, Q. R. Chen, Z. L. Li, B. C. Weng and T. S. Huang, Appl. Phys. Lett., 2007, 90, 34106.

9 N. Brun, R. Janot, C. Sanchez, H. Deleuze, C. Gervais, M. Morcrette and R. Backov, Energy Environ. Sci., 2010, 3, 824-830.

10 A. Staubitz, A. P. M. Robertson and I. Manners, Chem. Rev., 2010, 110, 4079-4124; A. C. Stowe, W. J. Shaw, J. C. Linehan, B. Schmid and T. Autrey, Phys. Chem. Chem. Phys., 2007, 15, 1831-1836; C. A. Morrison and M. M. Siddick, Angew. Chem., Int. Ed., 2004, 43, 4780-4782; W. T. Klooster, T. F. Koetzle, P. E. M. Siegbahn, T. B. Richardson and R. H. Crabtree, J. Am. Chem. Soc., 1999, 121, 6337-6343.

11 Z. T. Xiong, C. K. Yong, G. Wu, P. Chen, W. Shaw, A. Karkamkar, T. Autrey, M. O. Jones, S. R. Johnson, P. P. Edwards and W. F. David, Nat. Mater., 2008, 7, 138-141; H. Wu, W. Zhou and T. Yildirim, J. Am. Chem. Soc., 2008, 130, 14834-14839.

12 T. J. Groshens and R. A. Hollins, Chem. Commun., 2009, 3089-3091.

13 T. Hügle, M. F. Kühnel and D. Lentz, J. Am. Chem. Soc., 2009, 131, 7444-7446.

14 Y. H. Guo, X. B. Yu, W. W. Sun, D. L. Sun and W. N. Yang, Angew. Chem., Int. Ed., 2011, 50, 1087-1091; G. Soloveichik, J. H. Her, P. W. Stephens, Y. Gao, J. Rijssenbeek, M. Andrus and J. C. Zhao, Inorg. Chem., 2008, 47, 4290-4298; Z. G. Huang, J. Gallucci, X. N. A. Chen, T. Yisgedu, H. K. Lingam, S. G. Shore and J. C. Zhao, J. Mater. Chem., 2010, 20, 2743-2745.

15 J. Spielmann and S. Harder, J. Am. Chem. Soc., 2009, 131, 5064-5065; C. W. Yoon and L. G. Sneddon, J. Am. Chem. Soc., 2006, 128, 1399213993; V. Pons and R. T. Baker, Angew. Chem., Int. Ed., 2008, 47,
9600-9062; C. A. Morrison and M. M. Siddick, Angew. Chem., Int. Ed., 2004, 43, 4780-4782; L. Gao, Y. H. Guo, G. L. Xia and X. B. Yu, J. Mater. Chem., 2009, 19, 7826-7829.

16 P. G. Campbell, L. N. Zakharov, D. J. Grant, D. A. Dixon and S. Y. Liu, J. Am. Chem. Soc., 2010, 132, 3289-3291; A. D. Sutton, B. L. Davis, K. X. Bhattacharyya, B. D. Ellis, J. C. Gordon and P. P. Power, Chem. Commun., 2010, 46, 148-149.

17 A. Boultif and D. Louer, J. Appl. Crystallogr., 2004, 37, 724-731.

18 V. Favre-Nicolin and R. Cerny, J. Appl. Crystallogr., 2002, 35, 734 743.

19 Bruker AXS (2008): TOPAS V4.2: General profile and structure analysis software for powder diffraction data. - User's Manual, Bruker AXS, Karlsruhe, Germany.

20 C. Gervais, J. Maquet, F. Babonneau, C. Duriez, E. Framery, M. Vaultier, P. Florian and D. Massiot, Chem. Mater., 2001, 13, 1700-1707; A. Doroodian, J. E. Dengler, A. Genest, N. Rosch and B. Rieger, Angew. Chem., Int. Ed., 2010, 49, 1871-1873.

21 L. Mosegaard, B. Moller, J. E. Jorgensen, Y. Filinchuk, Y. Cerenius, J. C. Hanson, E. Dimasi, F. Besenbacher and T. R. Jensen, J. Phys. Chem. C, 2008, 112, 1299-1303; L. M. Arnbjerg, D. B. Ravnsbaek, Y. Filinchuk, R. T. Vang, Y. Cerenius, F. Besenbacher, J. E. Jorgensen, H. J. Jakobsen and T. R. Jensen, Chem. Mater., 2009, 21, 5772-5782.

22 R. J. Sension, B. Hudson and P. R. Callis, J. Phys. Chem., 1990, 94, 4015-4025; S. Gomes, H. Hagemann and K. Yvon, J. Alloys Compd., 2002, 346, 206-210.

23 P. Chen, Z. T. Xiong, J. Z. Luo, J. Y. Lin and K. L. Tan, J. Phys. Chem. B, 2003, 107, 10967-10970.

24 Y. H. Guo, G. L. Xia, Y. H. Zhu, L. Gao and X. B. Yu, Chem. Commun., 2010, 46, 2599-2601; Y. H. Guo, W. W. Sun, Z. P. Guo, H. K. Liu, D. L. Sun and X. B. Yu, J. Phys. Chem. C, 2010, 114, $12823-12827$. 